\title{
PROBLEM KETIDAKPATUHAN TERHADAP PUTUSAN MAHKAMAH KONSTITUSI TENTANG PENGUJIAN UNDANG-UNDANG ${ }^{1}$
}

\author{
Widayati \\ Dosen Fakultas Hukum Universitas Islam Sultan Agung (Unissula) Semarang \\ Jl. Raya Kaligawe KM. 4, Semarang \\ Email:widayati.winanto@gmail.com
}

\begin{abstract}
Article 24C Paragraph (1) of the 1945 Constitution of the The Republic of Indonesia authorizes the Constitutional Court to hear at the first and final level the decission of wich of to examine the law againts the Constitution. In the elucidation of Article 10 Paragraph (1) of the law of Constitutional Court, the final decission shall obtain a permanent legal force from the time of speech and no legal remedy can be taken. The final verdict of the Constitutional Court examining the law is immediately applicable, and some require the follow up of the legislators by forming new laws, or amending existing laws. Often, the legislators do not obey the Cosntitutional Court's decission. Non-compliance can occur because there are not sanctions againts non-compliance, and also the Constitutional Court does not haven an instrumental or execution in charge of ensuring the execution of its verdict. Therefore, efforts are needed to ensure that the Co nstitutional Court as a judicial institution remains authoritative and is not abandoned by justice seekers.
\end{abstract}

Keywords : non-compliance, Constitutional Court Decission.

\begin{abstract}
Abstrak
Pasal 24C ayat (1) Undang-Undang Dasar Negara Republik Indonesia Tahun 1945 memberikan kewenangan kepada Mahkamah Konstitusi untuk mengadili pada tingkat pertama dan terakhir yang putusannya bersifat final, salah satunya adalah menguji undang-undang terhadap UndangUndang Dasar. Dalam Penjelasan Pasal 10 ayat (1) Undang-Undang tentang Mahkamah Konstitusi, putusan final tersebut langsung memperoleh kekuatan hukum tetap sejak diucapkan dan tidak ada upaya hukum yang dapat ditempuh. Putusan final Mahkamah Konstitusi dalam menguji undang-undang ada yang langsung dapat dilaksanakan, dan ada yang memerlukan tindak lanjut dari pembentuk undang-undang dengan membentuk undang-undang baru, atau mengubah undang-undang yang sudah ada. Sering terjadi, pembentuk undang-undang tidak patuh pada putusan Mahkamah Konstitusi. Ketidakpatuhan dapat terjadi karena tidak ada sanksi terhadap ketidakpatuhan tersebut, dan juga Mahkamah Konstitusi tidak memiliki instrument atau lembaga eksekutor yang bertugas menjamin pelaksanaan putusannya. Untuk itu diperlukan upaya agar putusan Mahkamah Konstitusi yang bersifat final dan mengikat dipatuhi dan dilaksanakan, agar Mahkamah Konstitusi sebagai lembaga peradilan tetap berwibawa dan tidak ditinggalkan oleh para pencari keadilan.
\end{abstract}

Kata Kunci: ketidakpatuhan, Putusan Mahkamah Konstitusi

\section{A. PENDAHULUAN}

Peraturan perundang-undangan atau hukum tertulis disusun dalam tingkatan yang disebut dengan hierarki peraturan perundangundangan. Hal ini berkonsekuensi bahwa peraturan perundang-undangan yang lebih rendah tingkatannya tidak boleh bertentangan dengan peraturan perundang-undangan yang lebih tinggi. Jika terdapat materi muatan peraturan perundangundangan yang lebih rendah bertentangan dengan peraturan perundang-undangan yang lebih tinggi, maka dapat dilakukan pengujian.

\footnotetext{
Tulisan ini merupakan hasil penelitian kerjasama antara DPD RI dengan LPPM Unissula Semarang
} 
Pengujian peraturan perundang-undangan dapat dilakukan melalui mekanisme peradilan (justisial) ataupun mekanisme non justisial. Pengujian oleh lembaga peradilan disebut dengan judicial review, sedangkan pengujian yang dilakukan oleh selain lembaga peradilan dapat berupa legislative review (oleh Igislator) atau dapat pula berupa executive review (oleh pemerintah). ${ }^{1}$

Lembaga negara yang mempunyai kewenangan untuk melakukan pengujian peraturan perundang-undangan melalui mekanisme peradilan menurut Undang-Undang Dasar Negara Republik Indonesia Tahun 1945 adalah Mahkamah Agung dan Mahkamah Konstitusi. Kewenangan Mahkamah Agung adalah menguji peraturan perundang-undangan di bawah undang-undang terhadap undang-undang, sedangkan untuk pengujian undang-undang terhadap Undang-Undang Dasar dilakukan oleh Mahkamah Konstitusi.

Mahkamah Konstitusi sebagaimana ketentuan Pasal 24C ayat (1) Undang-Undang Dasar Negara Republik Indonesia Tahun 1945 sebagai salah satu pelaku kekuasaan kehakiman mempunyai kewenangan untuk mengadili pada tingkat pertama dan terakhir yang putusannya bersifat final, salah satunya adalah untuk menguji undang-undang terhadap UndangUndang Dasar. Artinya, putusan Mahkamah Konstitusi yang bersifat final tersebut harus dilaksanakan, karena berdasarkan Penjelasan Pasal 10 ayat (1) Undang-Undang Nomor 23 Tahun 2004 tentang Mahkamah Konstitusi, terhadap putusan Mahkamah Konstitusi tidak dapat dilakukan upaya hukum.

Putusan Mahkamah Konstitusi tentang pengujian Undang-Undang yang menjadi persoalan dalam pelaksanaannya adalah putusan yang tidak langsung dapat dilaksanakan. Hal ini berkaitan dengan putusan yang harus ditindaklanjuti dengan membentuk undangundang baru atau mengubah undang-undang yang sudah ada. Artinya pelaksanaan putusan tersebut memerlukan tindak lanjut dari pembentuk undang-undang.

\footnotetext{
1 Jimly Asshiddiqie, Hukum Acara Pengujian UndangUndang, Sekretariat Jenderal dan Kepaniteraan Mahkamah Konstitusi RI, Jakarta, 2006, hlm. 1-2
}

Meskipun Mahkamah Konstitusi dalam melakukan pengujian undang-undang terhadap Undang-Undang Dasar putusannya bersifat final dan mengikat, akan tetapi realitasnya kadangkadang putusan Mahkamah Konstitusi tersebut tidak dipatuhi atau diabaikan oleh pembentuk undang-undang. DPR dan Presiden sebagai lembaga pembentuk undang-undang seringkali tidak mematuhi putusan Mahkamah Konstitusi. Padahal, menurut ketentuan Pasal 10 ayat (1) huruf d Undang-Undang Nomor 12 Tahun 2011 tentang Pembentukan Peraturan Perundang-undangan, salah satu materi muatan undang-undang adalah tindak lanjut atas putusan Mahkamah Konstitusi. Kondisi tersebut mengakibatkan putusan Mahkamah Konstitusi seolah-olah tidak mempunyai makna, karena tidak ada sanksi bagi pembentuk undang-undang (DPR dan Presiden) yang tidak mematuhi dan tidak menindaklanjuti putusan Mahkamah Konstitusi. Oleh karena itu perlu dicari solusi agar putusan Mahkamah Konstitusi dalam menguji undang-undang terhadap UndangUndang Dasar dapat ditaati atau dipatuhi oleh pembentuk undang-undang.

\section{B. PEMBAHASAN}

\section{Peraturan Perundang-undangan}

Pengertian peraturan perundangundangan dikemukakan oleh beberapa ahli hukum, dan hampir semuanya mengarah kepada aturan hukum tertulis. Yuliandri memberikan pengertian peraturan perundangundangan dilihat dari peristilahan merupakan terjemahan dari wettelijke regeling. Kata wettelijke berarti sesuai dengan wet, dan kata wet pada umumnya diterjemahkan dengan undang-undang. Oleh karena itu kemudian wettelijke regeling diterjemahkan menjadi peraturan perundang-undangan. ${ }^{2}$

Moh. Mahfud MD memberikan pengertian peraturan perundang-undangan adalah semua hukum dalam arti luas yang dibentuk dengan cara tertentu, oleh pejabat yang berwenang dan dituangkan dalam bentuk tertulis. ${ }^{3}$

2 Yuliandri, Asas-Asas Pembentukan Peraturan Perundangan yang Baik, Gagasan Pembentukan Undang-Undang Berkelanjutan, PT RajaGrafindo Persada, Jakarta, 2011, hlm. 25

Moh. Mahfud MD, Konstitusi dan Hukum dalam Kontroversi Isu, Rajawali Pers, RajaGrafindo Persada, Jakarta, 2009, hlm. 255 
Sedangkan S.j. Fochema sebagaimana dikutip oleh Maria Farida mengemukakan istilah perundang-undangan (legislation, wetgeving atau gesetzgebung) dapat dilihat dari dua segi, yaitu segi proses pembentukannya dan dari produknya. Dilihat dari segi proses pembentukannya, perundang-undangan merupakan proses pembentukan/proses membentuk peraturan-peraturan negara, baik di tingkat pusat maupun di tingkat daerah. Dari segi produk, perundang-undangan adalah segala peraturan negara yang merupakan hasil pembentukan peraturan-peraturan, baik di tingkat pusat maupun di tingkat daerah. ${ }^{4}$

Pengertian peraturan perundangundangan menurut Pasal 1 angka 2 Undang-Undang Nomor 12 Tahun 2011 tentang Pembentukan Peraturan Perundangundangan adalah peraturan tertulis yang memuat norma hukum yang mengikat secara umum dan dibentuk atau ditetapkan oleh lembaga negara atau pejabat yang berwenang melalui prosedur yang ditetapkan dalam peraturan perundang-undangan.

Peraturan perundang-undangan (hukum tertulis) dalam sistem hukum Indonesia, disusun dalam suatu tingkatan yang disebut hierarki peraturan perundang-undangan. Susunan hierarkis peraturan perundangundangan mengandung konsekuensi bahwa suatu peraturan perundang-undangan yang lebih rendah tingkatannya tidak boleh bertentangan dengan peraturan perundangundangan yang lebih tinggi. Hal ini selaras dengan asas hukum lex superior derogat inferiori (hukum yang lebih tinggi mengalahkan hukum yang tingkatannya di bawahnya). Hal ini dimaksudkan agar tercipta kepastian hukum dalam sistem peraturan perundangundangan. Hierarki peraturan perundangundangan mengandung beberapa prinsip yaitu: ${ }^{5}$

a. Peraturan perundang-undangan yang lebih tinggi kedudukannya dapat dijadikan landasan atau dasar hukum

4 Maria Farida Indrati Soeprapto, IImu Perundangundangan, Dasar-dasar dan Pembentukannya, Penerbit Kanisius, Yogyakarta, 1998, hlm. 3.

5 Ni'matul Huda, Negara Hukum, Demokrasi dan Judicial Review, UII Press, Yogyakarta, 2005, hlm. 57 bagi peraturan perundang-undangan yang lebih rendah, atau peraturan perundang-undangan yang berada di bawahnya;

b. Peraturan perundang-undangantingkat lebih rendah harus bersumber atau memiliki dasar hukum dari suatu peraturan perundang-undangan yang tingkatannya lebih tinggi;

c. Isi atau materi muatan peraturan perundang-undangan yang lebih rendah tidak boleh menyimpangi atau bertentangan dengan materi muatan peraturan perundang-undangan yang lebih tinggi tingkatannya;

d. Suatu peraturan perundang-undangan hanya bisa dicabut atau diganti atau diubah dengan peraturan perundang-undangan yang lebih tinggi tingkatannya atau paling tidak dengan yang sederajat;

e. Peraturan perundang-undangan yang sejenis apabila mengatur materi yang sama, maka peraturan terbaru yang harus diberlakukan, walaupun tidak dengan secara tegas dinyatakan bahwa peraturan yang lama dicabut. Selain itu, peraturan yang mengatur materi yang lebih khusus harus diutamakan dari peraturan perundangundangan yang lebih umum.

Konsekuensi dari prinsip-prinsip hierarki peraturan perundang-undangan adalah harus ada mekanisme yang menjaga dan menjamin agar prinsip tersebut ditaati, tidak disimpangi atau dilanggar. Mekanisme untuk menjaga dan menjamin agar prinsip hierarki peraturan perundang-undangan ditaati yaitu ada sistem pengujian secara judisial (judicial review) atas setiap peraturan perundangundangan terhadap peraturan perundangundangan yang lebih tinggi tingkatannya atau terhadap peraturan perundang-undangan tingkat tertinggi yaitu Undang-Undang Dasar. Tanpa konsekuensi tersebut, hierarki peraturan perundang-undangan tidak mempunyai arti atau tidak bermakna.

Dalam sistem ketatanegaraan Indonesia, lembaga negara yang diberikan kewenangan 
untuk melakukan judicial review adalah Mahkamah Agung dan Mahkamah Konstitusi. Pengujian undang-undang apabila tidak sesuai dengan Undang-Undang Dasar Negara Republik Indonesia Tahun 1945 merupakan kewenangan Mahkamah Konstitusi, sedangkan Mahkamah Agung diberikan kewenangan untuk melakukan pengujian peraturan perundang-undangan dibawah undang-undang.

Jenis dan hierarki peraturan perundangundangan dalam sistem ketatanegaraan Indonesia diatur di dalam Pasal 7 ayat (1) Undang-Undang Nomor 12 Tahun 2011 tentang Pembentukan Peraturan Perundangundangan yaitu:
a. Undang-Undang Dasar Negara Republik Indonesia Tahun 1945
b. Ketetapan Majelis Permusyawaratan Rakyat
c. Undang-Undang/PeraturanPemerintah Pengganti Undang-Undang
d. Peraturan Pemerintah
e. Peraturan Presiden
f. Peraturan Daerah Provinsi; dan
g. Peraturan Daerah Kabupaten/Kota

\section{Judicial Review}

Pengujian peraturan perundangundangan merupakan suatu mekanisme yang dapat memastikan bahwa suatu peraturan perundang-undangan tidak bertentangan dengan peraturan perundangundangan yang lebih tinggi tingkatannya atau tidak bertentangan dengan peraturan perundang-undangan tingkat tertinggi yaitu Undang-Undang Dasar, dan tidak merugikan hak-hak warga negara yang dijamin oleh Undang-Undang Dasar. Pengujian peraturan perundang-undangan terdiri dari pengujian secara formal (formele toetsing) dan pengujian secara materiel (materiele toetsing). Pengujian secara formal adalah pengujian terhadap sah atau tidaknya prosedur pembentukan peraturan perundangundangan, bentuk resmi peraturan perundangundangan, dan lembaga pembentuk peraturan perundang-undangan. Sedangkan pengujian secara materiil adalah pengujian terhadap kesesuaian materi muatan peraturan perundang-undangan dengan materi muatan peraturan perundang-undangan yang lebih tinggi hierarkinya.

Menurut ajaran Hans Kelsen mengenai "Stufenbau des Recht" atau "The hierarchy of law" , peraturan perundang-undangan yang lebih rendah tidak boleh bertentangan dengan peraturan perundang-undangan yang lebih tinggi tingkatannya. Jika bertentangan, maka dapat diajukan judicial review. ${ }^{6}$ Sejarah kelahiran judicial review diyakini berawal dari Amerika Serikat dalam keputusan terhadap kasus Marbury melawan Madison pada tahun 1803. Mahkamah Agung Amerika Serikat yang dipimpin John Marshal ditantang untuk melakukan pengujian (review atau toetsing) atas Konstitusionalitas undang-undang yang ditetapkan oleh Konggres. John Marshal berpendapat bahwa jika ada ketidaksesuaian antara Konstitusi dengan undang-undang, maka harus memberlakukan hukum yang lebih tinggi dan menganulir undang-undang yang lebih rendah.

John Marshal mengemukakan alasan pentingnya judicial review yaitu: ${ }^{7}$

a. Hakim bersumpah untuk menjunjung tinggi konstitusi sehingga apabila ada peraturan yang bertentangan dengan konstitusi harus melakukan uji materi.

b. Konstitusi adalah the supreme law of the land sehingga harus ada pengujian terhadap peraturan yang di bawahnya agar the supreme law itu tidak dilangkahi isinya.

c. Hakim tidak boleh menolak perkara, sehingga kalau ada yang mengajukan permintaan judicial review harus dipenuhi.

Sejak adanya kasus Marbury versus Madison tersebut, ide tentang judicial review berkembang dan diikuti oleh negara-negara

6 Hans Kelsen, General Theory of Law and State, translated by Anders Wedberg, Russel \& Russel, New York, 1973. Dikutip kembali oleh Ni'matul Huda \& R. Nazriyah, Teori \& Pengujian Peraturan Perundang-undangan, Nusa Media, Bandung, 2011, hal. 24

Moh. Mahfud MD, Konstitusi ....... op.cit. hlm. 258 
lain, termasuk negara Indonesia Dalam praktek sehari-hari maupun di lingkungan fakultas-fakultas hukum kita, istilahistilah 'toetsingrecht', 'judicial review', dan 'constitutional review'sering dicampuradukkan pengertiannya satu sama lain. ${ }^{8} \mathrm{Judicial}$ review sering diidentikkan dengan toetsingrecht yang biasanya diterjemahkan dengan perkataan hak menguji, sehingga orang sering pula salah kaprah dengan mengacaukan penggunaan pengertian toetsingrecht dengan judicial review.

Upaya review atau pengujian kembali dapat saja dilakukan oleh pemerintah ataupun oleh lembaga legislatif. Jika dilakukan oleh pemerintah maka istilahnya adalah executive review, sedangkan pengujian oleh lembaga legislatif istilah yang digunakan adalah legislative review. ${ }^{9}$

Dalam Black's Law Dictionary, judicial review diartikan sebagai 'power of courts to review decisions of another department or level of government'..$^{10}$ Menurut Encyclopedia Britannica, judicial review is the power of court of a country to determine if acts of legislature and executive are constitutional. Sedangkan Brewer-Cariras mengartikan judicial review atau controle juridictionale adalah pengawasan kekuasaan kehakiman (judicial power) terhadap kekuasaan legislatif dan eksekutif. Brewer Cariras memandangnya sebagai tugas yang melekat dari pengadilan untuk menjamin tindakan hukum legislatif dan eksekutif sesuai dengan hukum tertinggi. ${ }^{11}$

Sedangkan hak menguji (toetsingrecht) dapat dibedakan menjadi dua yaitu hak menguji material (materiele toetsingrecht) dan hak menguji formil (formele toetsingrecht). Hak menguji material adalah suatu wewenang untuk menyelidiki dan kemudian menilai,

8 Jimly Assiddiqie, Model-model Pengujian Konstitusional di Berbagai Negara, Konstitusi Press, Jakarta, 2005, hlm. 7

9 Fatmawati, Hak Menguji (toetsingrecht) yang Dimiliki Hakim dalam Sistem Hukum Indonesia, Raja Grafindo Persada, Jakarta, 2005, hlm. IX

10 Henry Campbell Blact, Black's Law Dictionary with Pronunciations. 6th ed, United States of America, West Publishing Co, 1990, hlm. 849

11 Ni'matul Huda, Negara Hukum............... Op.Cit., hlm. 74 apakah suatu peraturan perundang-undangan isinya sesuai atau bertentangan dengan peraturan perundang-undangan yang lebih tinggi derajatnya, serta apakah suatu kekuasaan tertentu (verordenende macht) berhak mengeluarkan suatu peraturan perundang-undangan tertentu. ${ }^{12}$

Untuk hak menguji formal diartikan sebagai wewenang untuk menilai, apakah suatu produk legislatif seperti undang-undang misalnya terjelma melalui cara-cara (prosedur) sebagaimana telah ditentukan atau diatur dalam peraturan perundang-undangan yang berlaku ataukah tidak. ${ }^{13}$

Hak menguji material diadakan dalam rangka melindungi kaidah-kaidah Konstitusi. Seperti kata Cappellitti, ${ }^{14}$ untuk melindungi Konstitusi dapat dilakukan melalui dua sistem pengawasan yang lazim dilakukan, yaitu pengawasan secara politik dan pengawasan secara yudisial. Baik pengawasan secara politik maupun pengawasan secara yudisial dilakukan dengan cara menilai atau menguji (review), apakah suatu undang-undang atau peraturan perundang-undangan lainnya atau tindakan-tindakan pemerintah yang ada atau akan diadakan, bertentangan atau tidak dengan ketentuan-ketentuan lain yang dinilai. Wewenang menilai tersebut dalam kepustakaan kita lazim disebut sebagai hak menguji. Hak menguji diperlukan untuk mempertahankan Konstitusi, karena Konstitusi merupakan hukum yang tertinggi. Jadi hak menguji hanya relevan jika dipenuhi dua syarat, yaitu :

a. Harus terdapat Konstitusi tertulis yang dianggap sebagai hukum dan mempunyai kedudukan sebagai hukum yang tertinggi.

b. Konstitusi tertulis itu harus bersifat rigid, atau yang hanya diubah melalui tata cara atau prosedur khusus yang berbeda dengan tata cara mengubah undang-undang.

12 Sri Soemantri, Hak Menguji Material di Indonesia, Alumni, Bandung, 1986, hlm. 8

13 Ibid, hlm. 6

14 Rosjidi Ranggawidjaja dan Indra Perwira, Perkembangan Hak Menguji Materiil di Indonesia, Cita Bhakti Akademika, Bandung, 1996, hlm. 2 
Dalam sejarah ketatanegaran Indonesia, hak menguji materiil pernah diusulkan oleh Muh. Yamin pada waktu membahas Rancangan Undang-Undang Dasar dalam sidang BPUPKI. Muh Yamin menyatakan: ${ }^{15}$ "Mahkamah inilah yang setinggi-tingginya, sehingga dalam membanding undang-undang, Balai Agung inilah yang akan memutuskan apakah sejalan dengan hukum adat, syariah, dan Undang-Undang Dasar".

Akan tetapi ternyata dalam naskah Rancangan Undang-Undang Dasar usul Muh. Yamin tersebut belum tertampung, sehingga dalam komentarnya terhadap rancangan itu, Muh. Yamin menyatakan: "Balai Agung janganlah saja melaksanakan bagian kehakiman, tetapi hendaknya menjadi badan yang membanding, apakah undang-undang yang dibuat oleh Dewan Perwakilan Rakyat tidak melanggar Undang-Undang Dasar Republik atau bertentangan dengan hukum adat yang diakui, ataukah tidak bertentangan dengan syariah agama Islam". Meskipun Muh. Yamin tidak menggunakan istilah hak menguji materiil, tetapi yang dimaksud "membanding" tidak lain dari pada itu. ${ }^{16}$ Usul Muh. Yamin ditolak oleh Soepomo dengan alasan bahwa tenaga ahli kita belum begitu banyak. Selain itu menurut Soepomo hak menguji materiil merupakan konsekuensi dari Trias Politika. ${ }^{17}$

Perdebatan antara Muh. Yamin dan Soepomo tidak berlanjut karena mereka menginginkan pembahasan rancangan Undang-Undang Dasar cepat selesai agar proklamasi kemerdekaan dapat segera dilakukan. Usulan Muh. Yamin tentang hak menguji materiil tersebut akhirnya tidak tertampung dalam Undang-Undang Dasar 1945.

Pada masa berlakunya Konstitusi Republik Indonesia Serikat 1949, ketentuan Pasal

15 Sekretariat Negara Republik Indonesia, Risalah Sidang Badan Penyelidik usaha-usaha Persiapan Kemerdekaan Indonesia (BPUPKI) Panitia Persiapan Kemerdekaan Indonesia (PPKI), 28 Mei 1945 - 22 Agustus 1945, jakarta, 1998, hlm, 23

16 Rosjidi Ranggawidjaja dan Indra Perwira, Perkembangan........op.cit. hIm. 10

17 Sri Soemantri, Prosedur dan Sistem Perubahan Konstitusi, Alumni, Bandung, 1979, hlm. 341
$156^{18}$ mengatur mengenai hak menguji materiil, yang kewenangannya diserahkan kepada Mahkamah Agung dan badan-badan peradilan lain. Peraturan perundang-undangan yang dapat diuji meliputi undang-undang Daerah Bagian dan peraturan-peraturan lain termasuk peraturan-peraturan Federal kecuali UU Federal dan UU Darurat Federal sebagaimana diatur di dalam Pasal 130 ayat (2) Konstitusi RIS. ${ }^{19}$

Hak menguji materiil yang diatur di dalam Konstitusi Repunlik Indonesia Serikat 1949 belum sempat dipraktekkan karena kemudian digantikan dengan Undang-Undang Dasar Sementara Tahun 1950, yang berlakunya berdasarkan Undang-Undang Federal RIS Nomor 7 tahun 1950. Dalam Pasal 95 ayat (2) Undang-Undang Dasar Sementara Tahun 1950 dinyatakan bahwa Undang-Undang tidak dapat diganggu gugat, yang berarti terhadap Undang-Undang tidak dapat dilakukan uji materiil. Undang-Undang Dasar Sementara Tahun 1950 kemudian tidak berlaku dengan keluarnya Dekrit Presiden 5 Juli 1959, yang salah satu isinya adalah isinya anjuran untuk kembali ke Undang-Undang Dasar 1945.

Sebelum UUD 1945 diamandemen, didalamnya tidak mengatur mengenai hak menguji, baik secara formil maupun secara materiil. Meskipun demikian, di dalam Undang-Undang Nomor 14 Tahun 1970 tentang Pokok-Pokok Kekuasaan Kehakiman mengatur mengenai judicial review, meskipun ketentuan tersebut dalam kenyataannya tidak dapat menyentuh undang-undang dan tidak diimplementasikan. ${ }^{20}$

Ketentuan mengenai hak menguji baru

18 Pasal 156 ayat (1) Konstitusi RIS 1949 berbunyi: “Jika Mahkamah Agung atau pengadilan-pengadilan lain yang mengadili dalam perkara perdata atau dalam perkara hukum perdata beranggapan bahwa suatu ketentuan dalam peraturan ketatanegaraan atau undang-undang suatu daerah bagian berlawanan dengan konstitusi ini maka dalam keputusan kehakiman itu juga ketentuan itu dinyatakan dengan tegas tak menurut konstitusi."

19 Pasal 130 ayat (2) Konstitusi RIS 1949 berbunyi: "Undang-undang federal tidak dapat diganggu gugat."

20 Moh. Mahfud MD, Membangun Politik Hukum, Menegakkan Konstitusi, RajawaliGrafindo Persada, Jakarta, 2012, hlm. 131 
dikenal setelah adanya amandemen UUD 1945. Pasal 24A ayat (1) UUD Negara Republik Indonesia Tahun 1945 menyatakan bahwa Mahkamah Agung berwenang mengadili pada tingkat kasasi, menguji peraturan perundangundangan di bawah undang-undang terhadap undang-undang, dan mempunyai wewenang lainnya yang diberikan oleh undang-undang. Sedangkan dalam Pasal 24C ayat (1) UUD Negara Republik Indonesia Tahun 1945 antara lain menyatakan bahwa Mahkamah Konstitusi berwenang mengadili pada tingkat pertama dan terakhir yang putusannya bersifat final untuk menguji undang-undang terhadap Undang-Undang Dasar, memutus sengketa kewenangan lembaga negara yang kewenangannya diberikan oleh UndangUndang Dasar, memutus pembubaran partai politik, dan memutus perselisihan tentang hasil pemilihan umum.

Dari ketentuan Pasal 24A ayat (1) dan Pasal 24C ayat (1) UUD Negara Republik Indonesia Tahun 1945 tersebut, maka di Indonesia dikenal adanya dua lembaga negara yang berwenang untuk melakukan judicial review, yaitu Mahkamah Agung dan Mahkamah Konstitusi.

Mahkamah Konstitusi RI merupakan constitutional court yang ke-78 di dunia. Dibentuknya Mahkamah Konstitusi merupakan amanat Undang-Undang Dasar Negara Republik Indonesia Tahun 1945. Hal ini dapat dilihat di dalam Pasal III Atutan Peralihan Undang-Undang Dasar Negara Republik Indonesia Tahun 1945 yang menyatakan bahwa Mahkamah Konstitusi dibentuk selambat-lambatnya pada 17 Agustus 2003 dan sebelum dibentuk segala kewenangannya dilakukan oleh Mahkamah Agung. Untuk melaksanakan ketentuan Pasal III Aturan Peralihan tersebut kemudian dibentuk Undang-Undang Nomor 24 Tahun 2003 tentang Mahkamah Konstitusi.

Salah satu kewenangan Mahkamah Konstitusi menurut Pasal 24C ayat (1) Undang-Undang Dasar Negara Republik Indonesia Tahun 1945 adalah menguji Undang-Undang kesesuaiannya dengan Undang-Undang Dasar Negara Republik
Indonesia Tahun 1945. Pengujian oleh Mahkamah Konstitusi disebut dengan judicial review, karena Mahkamah Konstitusi merupakan lembaga judisial atau badan peradilan. Kewenangan Mahkamah Konstitusi dalam melakukan pengujian undang-undang diatur lebih lanjut di dalam Pasal 10 ayat (1) dan ayat (2) Undang-Undang Nomor 24 Tahun 2003 tentang Mahkamah Konstitusi sebagaimana telah diubah kedua kali dengan Undang-Undang Nomor 4 Tahun 2014 tentang Penetapan Peraturan Pemerintah Pengganti Undang-Undang Nomor 1 Tahun 2013 tentang Perubahan Kedua Atas Undang-Undang Nomor 24 Tahun 2003 tentang Mahkamah Konstitusi Menjadi Undang-Undang.

Judicial review oleh Mahkamah Konstitusi dilakukan terhadap Undang-Undang kesesuaiannya dengan Undang-Undang Dasar Negara Republik Indonesia Tahun 1945. Pengujian undang-undang yang menjadi kewenangan Mahkamah Konstitusi adalah menguji secara konstitusionalitas suatu undang-undang, yakni menguji sejauh mana Undang-Undang yang bersangkutan sesuai atau bertentangan (tegengesteld) dengan Undang-Undang Dasar Negara Republik Indonesia Tahun 1945. Constitutie is de hoogste wet, oleh karena itu, ketika Mahkamah Konstitusi memandang suatu Undang-Undang bertentangan dengan Undang-Undang Dasar Negara Republik Indonesia Tahun 1945, maka Undang-Undang tersebut tidak mempunyai kekuatan hukum mengikat.

Menurut Pasal 51 ayat (3) Undang-Undang Nomor 24 Tahun 2003 tentang Mahkamah Konstitusi, terdapat dua macam pengujian undang-undang, yaitu :

a. Pengujian undang-undang secara formal (formele toetsing), yaitu pengujian terhadap suatu undangundang dilakukan karena proses pembentukan undang-undang tersebut dianggap tidak memenuhi ketentuan berdasarkan UndangUndang Dasar.

b. Pengujian undang-undang secara materiil (materiele toetsing), yaitu 
pengujian terhadap suatu undangundang dilakukan karena terdapat materi muatan dalam ayat, pasal, dan/ atau bagian undang-undang yang dianggap pemohon bertentangan dengan Undang-Undang Dasar.

Dalam hal suatu pembentukan undangundang tidak memenuhi ketentuan pembentukan undang-undang berdasarkan Undang-Undang Dasar, maka undang-undang tersebut secara keseluruhan tidak mempunyai kekuatan hukum mengikat. Apabila suatu materi muatan ayat, pasal dan/atau bagian undang-undang dinyatakan oleh Mahkamah Konstitusi bertentangan dengan UndangUndang Dasar, maka materi muatan ayat, pasal dan/atau bagian undang-undang tersebut tidak lagi mempunyai kekuatan hukum mengikat.

Dalam melakukan pengujian undangundang terhadap Undang-Undang Dasar, Mahkamah Konstitusi tidak membatalkan keberlakuan suatu undang-undang, tetapi menyatakan bahwa suatu undang-undang, atau materi ayat, pasal dan/atau bagian undang-undang tidak lagi mempunyai kekuatan hukum mengikat (not legally binding). Mahkamah Konstitusi tidak dapat mengubah rumusan redaksi ayat, pasal dan/ atau bagian undang-undang. ${ }^{21}$

Selama kurun waktu berdirinya Mahkamah Konstitusi sejak tahun 2003 sampai sekarang, dari empat kewenangan yang dimiliki, kewenangan untuk pengujian undang-undang yang paling banyak dimohonkan ke Mahkamah Konstitusi. Hal ini menunjukkan bahwa produk undangundang yang ada selama ini dapat dikatakan cacat secara ideologis. Dengan kata lain, kualitas prosuk perundang-undangan sarat akan muatan yang berseberangan dengan konstitusi, tidak partisipatif, aspiratif, dan akuntabel. Dalam hal ini terdapat inkonsistensi dalam penyusunan undang-undang, baik dalam teks maupun isinya, bahkan dinilai undang-undang yang dibuat tersebut hanya diperuntukkan untuk kepentingan politik

21 Laica Marzuki, Berjalan-jalan di Ranah Hukum, Sekreteriat Jenderal dan Kepaniteraan Mahkamah Konstitusi RI, Jakarta, 2006, hIm. 102 sesaat yang mengesampingkan aspek keadilan. ${ }^{22}$

Pembagian tugas judicial review antara Mahkamah Agung dan Mahkamah Konstitusi menurut Jimly Assiddiqie sama sekali tidak ideal, karena dapat menimbulkan perbedaan putusan, atau putusan yang saling bertentangan antara Mahkamah Agung dan Mahkamah Konstitusi.

Perbedaan tersebut sebenarnya tidak dapat dilepaskan dari kenyataan bahwa memang pada awalnya Mahkamah Agung berwenang menguji peraturan perundangundangan di bawah undang-undang. Oleh karena itu, ketika terjadi kesepakatan dibentuknya Mahkamah Konstitusi dalam amandemen UUD 1945, Mahkamah Agung tetap diberikan kewenangan untuk melakukan judicial review. Hal ini dikarenakan pula memang ada negara lain yang dijadikan salah satu sumber inspirasi dalam merumuskan ketentuan tentang Mahkamah Konstitusi, yaitu Mahkamah Konstitusi Korea Selatan. Dalam Konstitusi Korea Selatan, kewenangan judicial review (constitutional review) atas undangundang memang diberikan kepada Mahkamah Konstitusi, tetapi kewenangan judicial review atas peraturan perundang-undangan di bawah undang-undang diberikan kepada Mahkamah Agung. ${ }^{23}$ Akan tetapi perlu dipertimbangkan bahwa kewenangan pengujian peraturan perundang-undangan diberikan kepada satu lembaga yaitu Mahkamah Konstitusi agar terjadi konsistensi materi muatan peraturan perundang-undangan.

\section{Poblem Ketidakpatuhan Terhadap Putusan Mahkamah Konstitusi Tentang Pengujian Undang-Undang}

Undang-Undang Dasar Negara Republik Indonesia Tahun 1945 di dalam Pasal 1 ayat (3) menyatakan bahwa negara Indonesia ialah negara hukum. Negara hukum Indonesia

22 Syukri Asy'ari, dkk, Model dan Implementasi Putusan Mahkamah Konstitusi dalam Pengujian UndangUndang (Studi Putusan Tahun 20113-2012), Jurnal Konstitusi, Volume 10, Nomor 4, Desember 2013, hlm. 678

23 Jimly Assiddiqie, Konstitusi dan Konstitusionalisme Indonesia, Mahkamah Konstitusi Press dan FH Universitas Indonesia, Jakarta, 2004, hlm. 189. 
menurut ketentuan Pasal 28 I ayat (5) Undang-Undang Dasar Negara Republik Indonesia Tahun 1945 merupakan negara hukum yang demokratis ${ }^{24}$ (democratische rechtstaat), artinya negara hukum Indonesia menggabungkan prinsip-prinsip rechtstaat dan rule of law. Apabila kita membaca UndangUndang Dasar 1945, baik Pembukaan maupun pasal-pasalnya, maka akan ditemukan unsur-unsur negara hukum menurut konsep Eropa Kontinental (rechtstaat) dan juga unsur-unsur negara hukum menurut konsep Anglo Saxon (rule of law). ${ }^{25}$ Sebelum UUD 1945 mengalami perubahan, ketentuan bahwa negara Indonesia adalah negara hukum yang demokratis sudah diatur di dalam Konstitusi RIS $1949^{26}$ dan di dalam UUDS 1950. ${ }^{27}$ Sebagaimana dalam UUD 1945 setelah perubahan, dalam Konstitusi RIS 1949 dan UUDS 1950 tidak ada pula penjelasan tentang apa yang dimaksud dengan negara hukum yang demokratis.

Negara Indonesia sebagai sebuah negara hukum yang condong pada civil law system, maka sumber hukum utamanya adalah hukum tertulis, dan pembentuk hukum utamanya adalah pembentuk undang-undang. Hukum tertulis di Indonesia disusun dalam suatu hierarki norma hukum, yang mengandung arti bahwa peraturan perundang-undangan yang lebih rendah hierarkinya, materi muatannya tidak boleh bertentangan dengan peraturan perundang-undangan yang lebih tinggi. Jika terjadi ketidaksesuaian materi muatan peraturan perundang-undangan yang

24 Pasal 28I ayat (5) Undang-Undang Dasar Negara Republik Indonesia Tahun 1945 berbunyi: "Untuk menegakkan dan melindungi hak asasi manusia sesuai dengan prinsip negara hukum yang demokratis, maka pelaksanaan hak asasi manusia dijamin, diatur, dan dituangkan dalam peraturan perundang-undangan."

25 Azhary, Negara hukum Indonesia, Analisis Yuridis Normatif Tentang Unsur-unsurnya, Ul-Press, Jakarta, 1995, hlm. 83

26 Pasal 1 ayat (1) Konstitusi RIS 1949 berbunyi: “ Republik Indonesia Serikat yang merdeka dan berdaulat ialah suatu negara hukum yang demokrasi dan berbentuk federal."

27 Pasal 1 ayat (1) UUDS 1950 berbunyi: "Republik Indonesia yang merdeka dan berdaulat ialah sustu negara hukum yang demokratis dan berbentuk kesatuan." lebih rendah dengan peraturan perundangundangan yang lebih tinggi, maka dapat dilakukan judicial review.

Undang-Undang sebagai produk politik, substansinya akan memuat kepentingankepentingan politik dari pembentuk UndangUndang itu sendiri. DPR sebagai pemegang kekuasaan membentuk Undang-Undang, anggotanya merupakan perwakilan politik yang diusung oleh partai-partai politik. Oleh karena itu, dalam pembentukan UndangUndang dapat dipastikan akan mencerminkan kehendak politik dari partai-partai politik, terutama partai politik yang mendominasi keanggotaan di DPR.

Substansi Undang-Undang yang bermuatan politik tersebut boleh diuji oleh institusi hukum, dengan harapan terjadi kesesuaian antara kehendak politik dengan kehendak masyarakat, dan juga sesuai dengan kehendak Undang-Undang Dasar. Oleh karena itu, pihak yang menganggap hak dan/atau kewenangan konstitusionalnya dirugikan sebagai akibat dibentuknya suatu Undang-Undang, dapat mengajukan judicial review kepada Mahkamah Konstitusi. Hak konstitusional yang dimaksud adalah hakhak yang diatur dalam Undang-Undang Dasar Negara Republik Indonesia Tahun 1945. Judicial review ini penting dalam rangka menjaga tertib hukum, agar tidak terjadi pertentangan materi muatan antar peraturan perundang-undangan.

Pihakyang dapatmengajukan permohonan judicial review ke Mahkamah Konstitusi yaitu perorangan warga negara Indonesia (termasuk kelompok orang yang mempunyai kepentingan yang sama), kesatuan masyarakat hukum adat sepanjang masih hidup dan sesuai dengan perkembangan masyarakat dan prinsip Negara kesatuan Republik Indonesia yang diatur dalam undang-undang, badan hukum publik atau privat, atau lembaga negara.

Mahkamah Konstitusi sebagai salah satu pelaku kekuasaan kehakiman yang tidak mempunyai badan-badan peradilan di bawah Mahkamah Konstitusi sebagaimana Mahkamah Agung yang mempunyai badan- 
badan peradilan di bawahnya, maka putusan Mahkamah Konstitusi menurut ketentuan pasal 24C Undang-Undang Dasar Negara Republik Indonesia Tahun 1945 bersifat final. Putusan Mahkamah Konstitusi memperoleh kekuatan hukum tetap sejak selesai diucapkan dalam sidang pleno terbuka untuk umum, dan tidak ada upaya hukum yang dapat ditempuh untuk menganulir putusan Mahkamah Konstitusi.

Putusan Mahkamah Konstitusi yang berkaitan dengan pengujian Undang-Undang akan mengabulkan permohonan pemohon jika permohonan beralasan. Mahkamah Konstitusi dalam putusannya menyatakan dengan tegas materi muatan ayat, pasal, dan/atau bagian dari undang-undang yang bertentangan dengan Undang-Undang Dasar Negara Republik Indonesia Tahun 1945, sehingga tidak mempunyai kekuatan hukum mengikat. Undang-undang yang diuji oleh Mahkamah Konstitusi tetap berlaku, sebelum ada putusan Mahkamah Konstitusi yang menyatakan bahwa undang-undang tersebut bertentangan dengan Undang-Undang Dasar Negara Republik Indonesia tahun 1945.

Putusan Mahkamah Konstitusi yang berkaitan dengan pengujian undangundang terhadap Undang-Undang Dasar Negara Republik Indonesia Tahun 1945 ini disampaikan kepada Dewan Perwakilan Rakyat, Dewan Perwakilan Daerah, Presiden, dan Mahkamah Agung.

Penyampaian putusan Mahkamah Konstitusi kepada DPR dan Presiden dimaksudkan agar DPR dan Presiden sebagai lembaga negara pembentuk undang-undang segera menindaklanjuti putusan Mahkamah Konstitusi tersebut. Penyampaian putusan Mahkamah Konstitusi kepada Dewan Perwakilan Daerah dimaksudkan agar Dewan Perwakilan Daerah sebagai salah satu kamar dari parlemen Indonesia mengetahi adanya undang-undang yang telah dibatalkan oleh Mahkamah Konstitusi. Sedangkan penyampaian putusan Mahkamah Konstitusi kepada Mahkamah Agung dimaksudkan agar Mahkamah Agung ketika menguji peraturan perundang-undangan di bawah UndangUndang mendasarkan pada Undang-Undang yang telah mengalami pegujian di Mahkamah Konstitusi. Dan ketika Mahkamah Agung sedang melakukan pengujian terhadap peraturan perundang-undangan di bawah undang-undang, ketika proses pengujian suatu Undang-Undang sedang dilakukan oleh Mahkamah Konstitusi, maka pengujian peraturan perundang-undangan di bawah undang-undang yang sedang dilakukan oleh Mahkamah Agung wajib dihentikan sampai ada putusan Mahkamah Konstitusi.

Meskipun Mahkamah Konstitusi ketika menguji Undang-Undang putusannya final dan juga mengikat, akan tetapi realitasnya kadang-kadang putusan Mahkamah Konstitusi tersebut tidak ditindaklanjuti atau diabaikan oleh lembaga pembentuk Undang-Undang (DPR dan Presiden), sehingga terdapat kendala terhadap pelaksanaan putusan Mahkamah Konstitusi. Padahal putusan Mahkamah Konstitusi bersifat erga omnes, artinya putusan Mahkamah Konstitusi tersebut berlaku tidak hanya bagi pemohon judicial review (pihak-pihak yang berperkara) yang memohonkan pengujian undang-undang tersebut, tetapi juga bagi seluruh pihak yang terkait dengan putusan Mahkamah Konstitusi.

Mahkamah Konstitusi sebagai lembaga peradilan seharusnya putusannya dipatuhi dan ditindaklanjuti, karena hal tersebut merupakan kewajiban hukum bagi lembaga pembentuk undang-undang, dan juga pelaksanaan putusan Mahkamah Konstitusi merupakan upaya untuk memenuhi hak-hak konstitusional warga negara yang diberikan oleh Undang-Undang Dasar Negara Republik Indonesia Tahun 1945, terutama mereka yang mengajukan permohonan judicial review kepada Mahkamah Konstitusi.

Ketidakpatuhan terhadap putusan Mahkamah Konstitusi dapat terjadi karena Mahkamah Konstitusi tidak memiliki instrument atau lembaga eksekutor yang bertugas menjamin pelaksanaan putusan Mahkamah Konstitusi yang bersifat final dan mengikat. Putusan final dan mengikat Mahkamah Konstitusi sangat bergantung pada otoritas publik di luar Mahkamah 
Konstitusi untuk menindaklanjuti putusan final dan mengikat tersebut. ${ }^{28}$ Meskipun di dalam Pasal 24C ayat(1) Undang-Undang Dasar Negara Republik Indonesia Tahun 1945 hanya menyatakan bahwa putusan Mahkamah Konstitusi bersifat final, tidak diikuti dengan kata "mengikat", akan tetapi dapat ditafsirkan bahwa putusan final Mahkamah Konstitusi tersebut berarti mengikat pihakpihak yang berkaitan dengan putusan Mahkamah Konstitusi, begitu putusan itu selesai diucapkan.

Dasar pelaksanaan putusan Mahkamah Konstitusi terletak pada kesadaran hukum para pihak yang terkait dengan putusan, untuk mematuhi putusan, tanpa adanya upaya pemaksaan. Oleh karena itu, implementasi putusan Mahkamah Konstitusi memerlukan kesadaran moral dan juga kesadaran hukum para lembaga yang terkait ${ }^{29}$

Pelaksanaan putusan Mahkamah Konstitusi juga bersifat otomatis, tidak memerlukan lembaga eksekutor. Oleh karena itu memerlukan kesadaran moral dan juga kesadaran hukum bagi pihak-pihak yang terkait dengan putusan Mahkamah Konstitusi, karena pelaksanaan putusan Mahkamah Konstitusi juga merupakan kewajiban konstitusional bagi pihak-pihak yang terkait dengan putusan Mahkamah Konstitusi.

Pelaksanaan putusan Mahkamah Konstitusi yang bersifat otomatis dan juga tidak ada lembaga eksekutor berpotensi menyebabkan ketidakpatuhan terhadap putusan Mahkamah Konstitusi. Tidak ada sanksi bagi para pihak yang tidak mematuhi dan tidak menindaklanjuti putusan Mahkamah Konstitusi.

Ketidakpatuhan pihak-pihak yang berperkara termasuk pula lembaga pembentuk undang-undan pelaksana putusan Mahkamah Konstitusi, sedikit banyak dapat mempengaruhi kewibawaan Mahkamah Konstitusi, dan bahkan jika ketidakpatuhan itu terjadi berulang-ulang,

28 Bachtiar, Problematika Implementasi Putusan Mahkamah Konstitusi pada Pengujian UU terhadap UUD, Raih Asa Sukses, Jakarta, 2015, hal. 233

29 Ibid. hlm. 232 masyarakat semakin tidak percaya kepada Mahkamah Konstitusi. ${ }^{30}$ Apabila problem pelaksanaan putusan Mahkamah Konstitusi terus berlanjut seperti sekarang ini, maka bisa jadi pada masa yang akan datang, Mahkamah Konstitusi akan ditinggalkan oleh para pencari keadilan. Persoalannya adalah, tidak ada peraturan perundangundangan atau ketentuan formal yang mengatur pelaksanaan putusan Mahkamah Konstitusi. DPR dan Pemerintah sebagai pihak yang secara langsung terkait dengan putusan Mahkamah Konstitusi, seharusnya merespon positif dan melaksanakan putusan Mahkamah Konstitusi, dengan segera menindaklanjutinya.

Mahkamah Konstitusi tidak mempunyai daya paksa untuk pelaksanaan putusannya, dan tidak dapat mengeksekusi sendiri putusannya, oleh karena itu diperlukan kesadaran dan tindakan konkrit dari DPR dan Pemerintah sebagai lembaga negara pembentuk undang-undang, agar putusan Mahkamah Konstitusi mempunyai makna, dan tidak mubadzir. DPR dan pemerintah mempunyai kewajiban konstitusional untuk melaksanakan putusan Mahkamah Konstitusi. Selain DPR dan Presiden, diperlukan pula kerjasama berbagai pihak agar putusan Mahkamah Konstitusi sebagai sebuah produk hukum dapat dilaksanakan.

DPR dan Presiden sebagai pembentuk undang-undang, yang mestinya menginginkan undang-undang yang dibentuknya ditaati, harus memberikan contoh untuk taat aturan hukum, salah satunya dengan mematuhi dan melaksanakan putusan Mahkamah Konstitusi, karena putusan Mahkamah Konstitusi merupakan salah satu produk hukum di Indonesia. Bagaimana masyarakat dapat dituntut untuk taat pada aturan hukum, jika lembaga negara pembentuk hukum sendiri tidak mentaati aturan hukum.

Mahkamah Konstitusi sebagai pengawal dan penafsir konstitusi, mempunyai arti bahwa, Mahkamah Konstitusi ketika melakukan tafsir terhadap Konstitusi untuk pengujian undang-undang, kemungkinan akan terjadi,

$30 \quad$ Ibid. hlm. 236 
Mahkamah Konstitusi telah mengubah Konstitusi tanpa mengubah teksnya. Oleh karena itu, untuk menjaga tertib hukum dengan asas bahwa peraturan perundangundangan yang hierarkinya lebih rendah tidak boleh bertentangan dengan peraturan perundang-undangan yang lebih tinggi, maka ketika Mahkamah Konstitusi memutuskan suatu undang-undang materi muatannya bertentangan dengan Undang-Undang Dasar Negara Republik Indonesia Tahun 1945, harus segera dipatuhi dan ditindaklanjuti oleh DPR dan Presiden dengan segera mengubah undang-undang tersebut untuk disesuaikan dengan putusan Mahkamah Konstitusi.

Jalan keluar yang dapat ditawarkan agar putusan Mahkamah Konstitusi dipatuhi dan segera dilaksanakan oleh DPR dan Presiden adalah Mahkamah Konstitusi dalam putusannya memuat tentang batas waktu bagi DPR dan Presiden untuk melakukan perubahan terhadap undang-undang yang sudah diputus oleh Mahkamah Konstitusi. Jika batas waktu yang telah ditentukan di dalam putusan Mahkamah Konstitusi tidak ditindaklanjuti oleh DPR dan Presiden untuk segera mengubah undang-undang, maka dikatakan bahwa DPR dan Presiden telah melakukan contempt of constitution atau penghinaan terhadap konstitusi. Atau bahkan dapat pula dikatakan DPR dan Presiden telah melakukan contempt of court atau penghinaan terhadap pengadilan, karena Mahkamah Konstitusi sebagai salah satu pelaku kekuasaan kehakiman di Indonesia merupakan lembaga peradilan.

Apabila terhadap putusan Mahkamah Konstitusi tetap tidak dilakukan perubahan undang-undang yang telah diuji oleh Makamah Konstitutsi, maka semua pihak yang berkaitan dengan putusan Mahkaman Konstitusi tetap melakukan tugas dan fungsinya sesuai dengan tafsir Mahkamah Konstitusi. Hal tersebut dapat dilakukan karena putusan Mahkamah Konstitusi adalah salah satu produk hukum di Indonesia yang kedudukannya sederajat atau bahkan dapat dikatakan lebih tinggi dari pada undang-undang. Jadi jika sudah ada putusan Mahkamah Konstitusi, maka para pihak yang terkait dengan putusan Mahkamah Konstitusi menjalankan fungsinya sesuai putusan Mahkamah Konstitusi, meskipun belum dilakukan perubahan terhadap undangundang yang dikabulkan permohannya oleh Mahkamah Konstitusi. Karena ketika putusan Mahkamah Konstitusi dimuat di dalam Berita Negara Republik Indonesia, putusan Mahkamah Konstitusi tersebut berlaku sebagai perubahan terhadap undang-undang yang yang telah diuji oleh Mahkamah Konstitusi.

\section{PENUTUP}

\section{Kesimpulan}

Berdasarkan uraian di atas, berkaitan dengan pelaksanaan putusan Mahkamah Konstitusi sampai pada kesimpulan bahwa Mahkamah Konstitusi dalam melakukan pengujian undang-undang kesesuaianya dengan Undang-Undang Dasar Negara Republik Indonesia Tahun 1945 putusannya bersifat final dan mengikat. Realitasnya kadang-kadang putusan Mahkamah Konstitusi tersebut diabaikan dan tidak ditindaklanjuti oleh DPR dan Presiden sebagai lembaga pembentuk undang-undang.

Terdapat kendala dalam pelaksanaan putusan Mahkamah Konstitusi, dan tidak ada sanksi bagi lembaga pembentuk undang-undang yang mengabaikan dan tidak mematuhi putusan tersebut. Hal ini karena Mahkamah Konstitusi tidak memiliki instrumen atau lembaga eksekutor yang menjamin implementasi putusannya. Mahkamah Konstitusi juga tidak mempunyai daya paksa dan tidak dapat mengeksekusi sendiri putusannya.

\section{Saran}

Diperlukan kesadaran moral dan juga kesadaran hukum dari pihak-pihak yang terkait dengan putusan Mahkamah Konstitusi, karena pelaksanaan putusan Mahkamah konstitusi juga merupakan kewajiban konstitusional pihak-pihak yang terkait dengan putusan tersebut. Oleh karena itu, perlu dipertimbangkan untuk pemberian sanksi bagi pihak-pihak terkait yang tidak 
melaksanakan putusan Mahkamah Konstitusi, karena dapat dikatakan pihak-pihak tersebut telah melakukan contempt of constitution dan contempt of court, karena Mahkamah Konstitusi merupakan lembaga negara yang berwenang menafsirkan konstitusi, dan Mahkamah Konstitusi merupakan lembaga peradilan.

Agar putusan Mahkamah Konstitusi yang berkaitan dengan pengujian undangundang dan harus ada tindak lanjut untuk membentuk undang-undang baru atau mengubah undang-undang yang sudah ada dapat dipatuhi, upaya yang dapat dilakukan adalah dengan memuat tentang batas waktu bagi DPR dan Presiden untuk melakukan perubahan terhadap undang-undang yang sudah diputus oleh Mahkamah Konstitusi. Selain itu dengan cara melakukan sosialisasi putusan Mahkamah Konstitusi secara luas kepada lembaga-lembaga negara dan masyarakat, tidak sekedar dimuat di dalam Berita Negara Republik Indonesia.

\section{DAFTAR PUSTAKA}

Azhary. Negara hukum Indonesia, Analisis Yuridis Normatif Tentang Unsur-unsurnya. Jakarta : UI-Press. 1995

Bachtiar, Problematika Implementasi Putusan Mahkamah Konstitusi pada Pengujian UU terhadap UUD. Jakarta : Raih Asa Sukses. 2015

Fatmawati, Hak Menguji (toetsingrecht) yang Dimiliki Hakim dalam Sistem Hukum Indonesia. Jakarta : Raja Grafindo Persada, 2005

Henry Campbell Blact, Black's Law Dictionary with Pronunciations. 6th ed, United States of America : West Publishing Co.1990

Jimly Assiddiqie. Konstitusi dan Konstitusionalisme Indonesia. Jakarta : Mahkamah Konstitusi Press dan FH Universitas Indonesia. 2004

: Konstitusi Press. 2005

. Hukum Acara Pengujian Undang-Undang Jakarta : Sekretariat Jenderal dan Kepaniteraan Mahkamah Konstitusi RI. 2006

Maria Farida Indrati Soeprapto, IImu Perundang-undangan, Dasar-dasar dan Pembentukannya. Yogyakarta : Penerbit Kanisius. 1998

M. Laica Marzuki. Berjalan-jalan di Ranah Hukum. Jakarta : Sekretariat Jenderal dan Kepaniteraan Mahkamah Konstitusi RI. 2006

Moh. Mahfud MD. Konstitusi dan Hukum dalam Kontroversi Isu, Jakarta : Rajawali Pers PT RajaGrafindo Persada. 2009

Persada. 2012

. Membangun Politik Hukum, Menegakkan Konstitusi. Jakarta : RajaGrafindo

Ni'matul Huda. Negara Hukum, Demokrasi dan Judicial Review. Yogyakarta : UII Press. 2005

Rosjidi Ranggawidjaja dan Indra Perwira, Perkembangan Hak Menguji Materiil di Indonesia. Bandung : Cita Bhakti Akademika. 1996

Sekretariat Negara Republik Indonesia, Risalah Sidang Badan Penyelidik usaha-usaha Persiapan Kemerdekaan Indonesia (BPUPKI) Panitia Persiapan Kemerdekaan Indonesia (PPKI), 28 Mei 1945 - 22 Agustus 1945, Jakarta, 1998 
Sri Soemantri. Prosedur dan Sistem Perubahan Konstitusi. Bandung : Alumni. 1979 . Hak Menguji Material di Indonesia. Bandung : Alumni. 1986

Syukri Asy'ari, dkk, Model dan Implementasi Putusan Mahkamah Konstitusi dalam Pengujian Undang-Undang (Studi Putusan Tahun 20113-2012), Jurnal Konstitusi. Volume 10. Nomor 4. Desember 2013

Yuliandri, Asas-Asas Pembentukan Peraturan Perundangan yang Baik, Gagasan Pembentukan Undang-Undang Berkelanjutan. Jakarta : PT RajaGrafindo Persada. 2011

Undang-Undang Dasar Republik Indonesia tahun 1945

Konstitusi Republik Indonesia Serikat 1949

Undang-Undang Dasar Sementara 1950

Undang-Undang Dasar Negara Republik Indonesia Tahun 1945

Undang-Undang Nomor 12 tahun 2011 tentang Pembentukan Peraturan Perundang-undangan 